\title{
THE KARÁCSONKŐ CASTLE: AN OUTPOST ON THE EASTERN SIDE OF THE CARPATHIANS
}

\author{
ANDRás Sófalvi ${ }^{1}$ \\ Hungarian Archaeology Vol. 10 (2021), Issue 4, pp. 27-38. https://doi.org/10.36338/ha.2021.4.3
}

The concept of an "outpost garrison" is hardly to be found in medieval written sources or among the terms used by medieval historians and archaeologists, but the title - borrowed from a novel by Jenö Rejtö - is not a mere catchphrase but conveys a substantial message, as we will see in this paper. Since their discovery half a century ago, the medieval artefacts, mainly weapons, of the Karácsonkö Castle have not received sufficient attention in Hungarian archaeological research. They are alien to the context, as the fortification is located on the Moldavian side of the Eastern Carpathians, beyond the historical borders of the Kingdom of Hungary, which have become fixed by the early modern and modern period. The main topics of my analysis are the relationship of the fortification with the contemporary Hungarian castle organisation, the evaluation of its role in border defence and politics, and its destruction. ${ }^{2}$

Keywords: Karácsonkő, earthwork with wooden structure, castle organization, border defence, Árpád age, weapons, bracteate, Mongol invasion

\section{THE CASTLE BEYOND THE MOUNTAINS}

The castle of Karácsonkő is a fortification with important Iron Age precursors, identical to the ancient Petrodava mentioned by Ptolemy. The excavations carried out here in the 1960s revealed a medieval archaeological site, some elements of which were unparalleled in the contemporary Moldovan finds and testified to western connections behind the mountains. A comprehensive overview of the castle's medieval artefacts has been published (SCORPAN, 1965) and it was later supplemented by the publication of further finds (SPINEI, 1982). Until now, questions concerning this castle have been addressed mainly by Romanian researchers, who usually emphasized the unique characteristics of the finds, giving room to various interpretations (centre of a Romanian principality, i.e. cnezat, Hungarian expansion to the east with Romanian participation from Transylvania, trade and political relations, etc.). The topic is by no means exhausted. Regrettably, no further excavations have been carried out in the castle, so progress can be expected mainly from comparative studies of the artefacts and from the wider spatial context and analysis of the site.

\section{NAME, GEOGRAPHICAL LOCATION AND CHARACTERISTICS OF THE CASTLE}

East of the Ceahlău and Tarcău Mountains, which are smaller blocks of the Eastern Carpathians, in the mouth of the valley of the Bistrița Aurie River, the castle of Karácsonkő (in Romanian: cetatea Bâtca Doamnei) is located near the present-day town of Piatra Neamt, [in word-for-word translation: German Stone] (Fig. 1), several kilometres beyond the historic border of the Kingdom of Hungary. The earliest occurrence of the toponym from 1395 (in terra nostra Molduana ante villam Karachonkw - see MáLYUSZ 1951, 3801) confirms its Hungarian origin. The settlement had a significant Hungarian population in the Middle Ages, who left behind a number of place names, such as Kövesd Stream (in Romanian: Cuejd) (MikeCs 1943, 459, note 3).

Haáz Rezső Museum, Odorheiu Secuiesc, Romania. E-mail: sofalvi@hotmail.com

This article is part of a comprehensive research on the castle of Karácsonkő and its historical background and connections on both sides of the Carpathians. It is primarily concerned with the archaeological evaluation of the finds, and the historical context of my findings will be discussed in more detail in a longer paper. My research has been supported by the Domus Hungarica Scientiarium et Artium fellowship programmes of the Hungarian Academy of Sciences (4/2021/HTMT, 1944/13/2021/HTMT). 


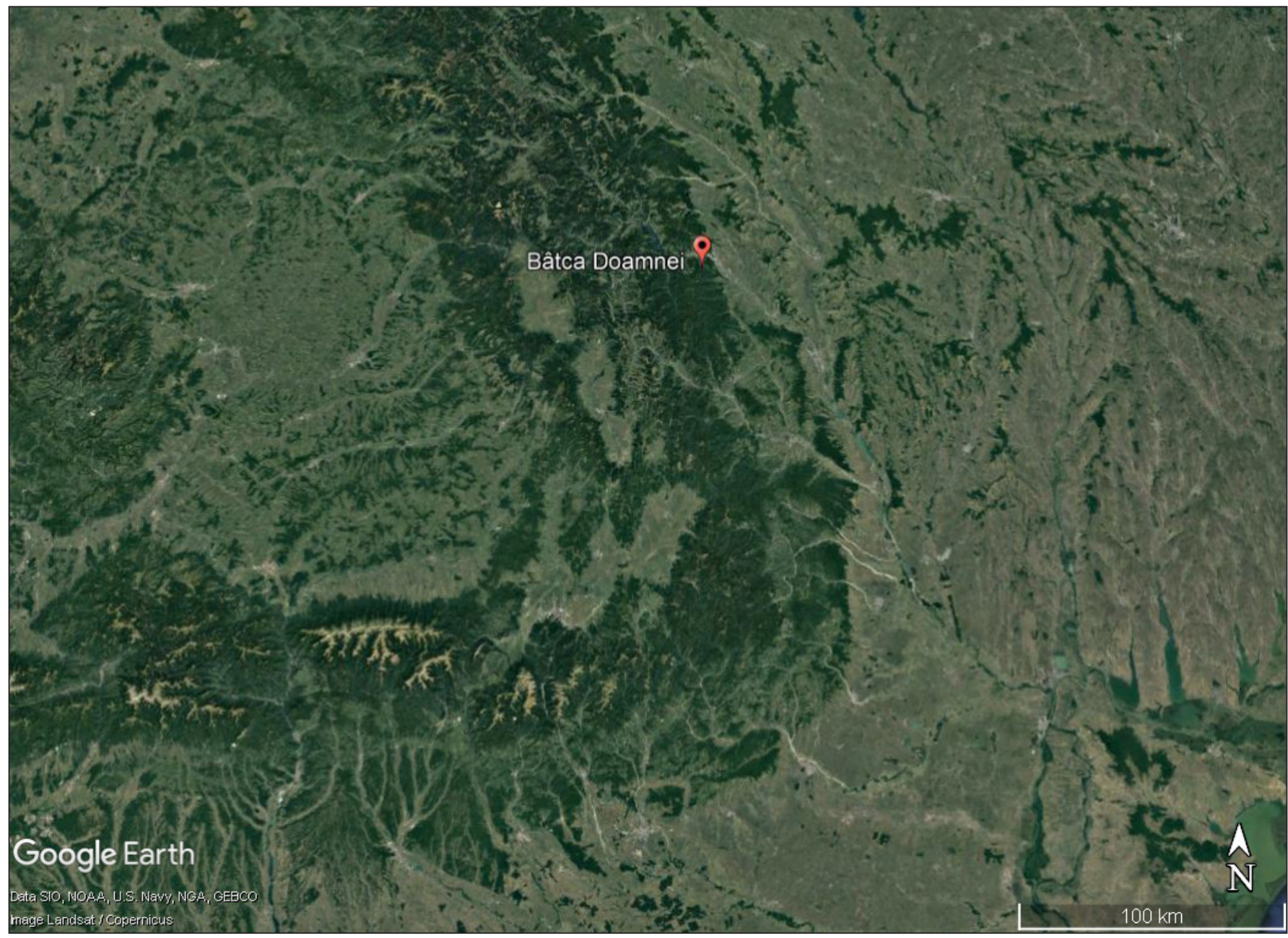

Fig. 1. Karácsonkö's position in the Carpathians (source: Google Earth)

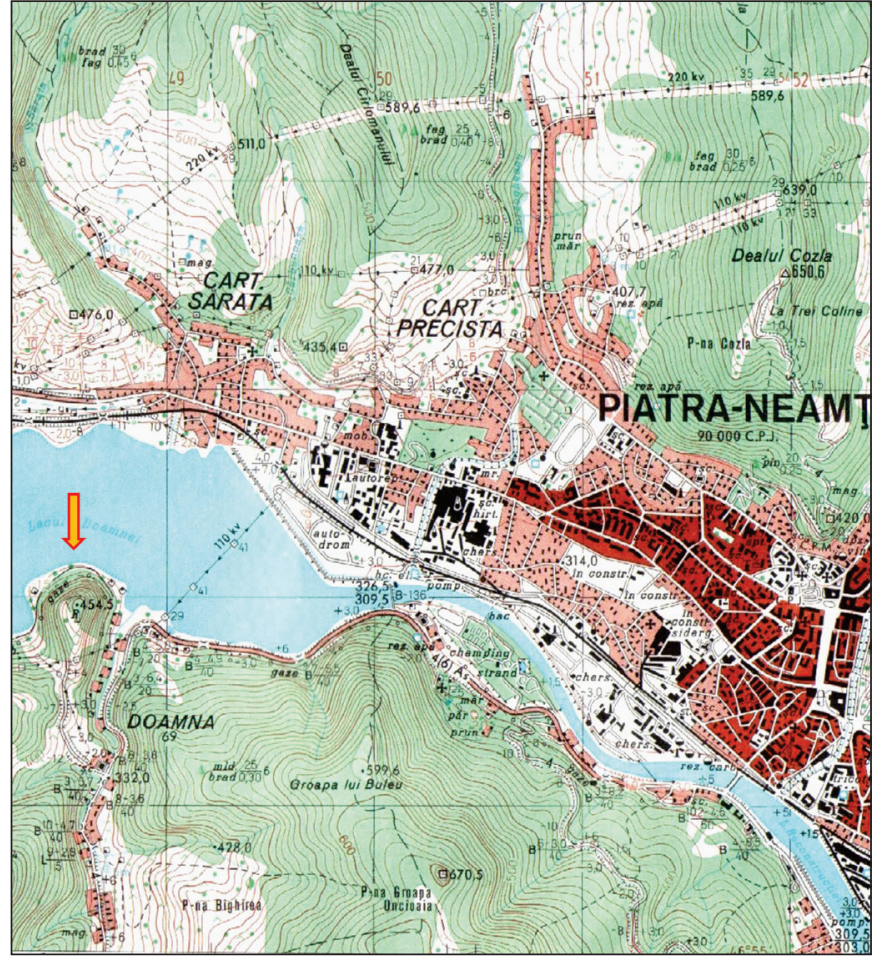

Fig. 2. Karácsonkő's topography on a 1:5000 scale map

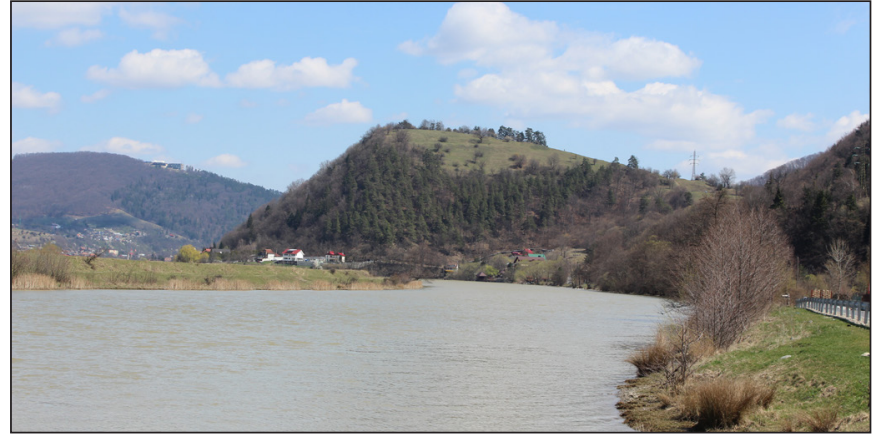

Fig. 3. The castle hill from the west (photo by the author)

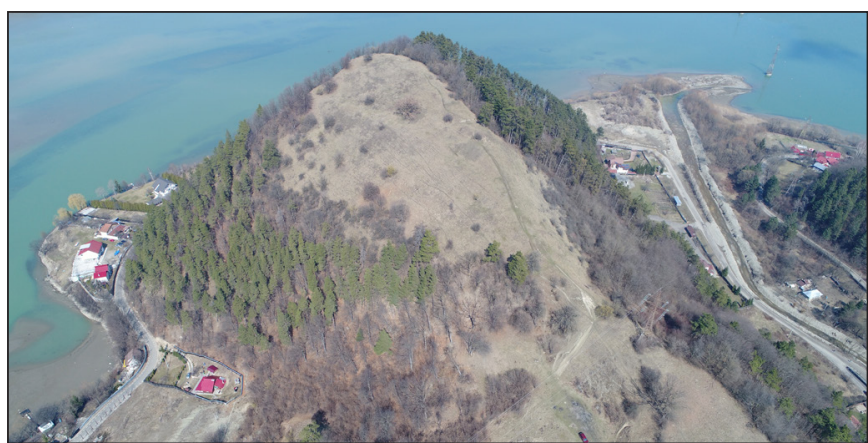

Fig. 4. Aerial photo of the castle hill from the south (CloudScale Digital Ltd.) 
András Sófalvi • The Karácsonkö Castle: an Outpost on the Eastern Side of the Carpathians

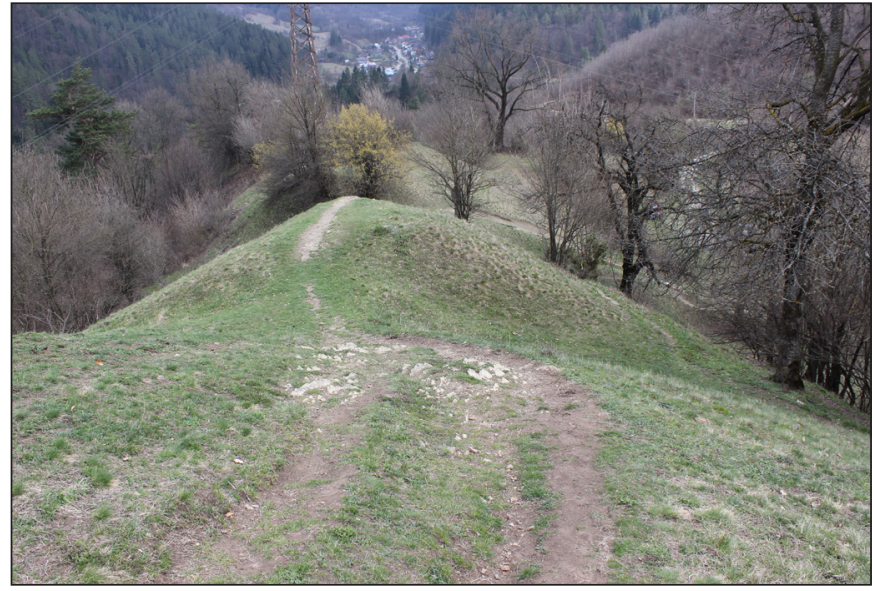

Fig. 5. Earthworks bordering the ridge from the south (photo by the author)
The castle stands on the southern side of the Bistrița Aurie valley, on a hill overlooking the river (457 $\mathrm{m})$, west of the mouth of the collateral Doamnei (Lady's) Stream (Figs 2-4), at a strategic point. The north-south elevation could be approached from the south via a narrow ridge cut through by four ditches in the rock (Fig. 5). These date from the late Iron Age according to archaeological research, but their medieval renewal/reuse is likely. $100-150 \mathrm{~m}$ to the north of them, the remains of a Dacian stone wall (opus quadratum) made of regularly shaped and clay-cemented stone blocks were discovered, and above them the burnt remains of a medieval palisade were observed (Fig. 6). The existence of a medieval

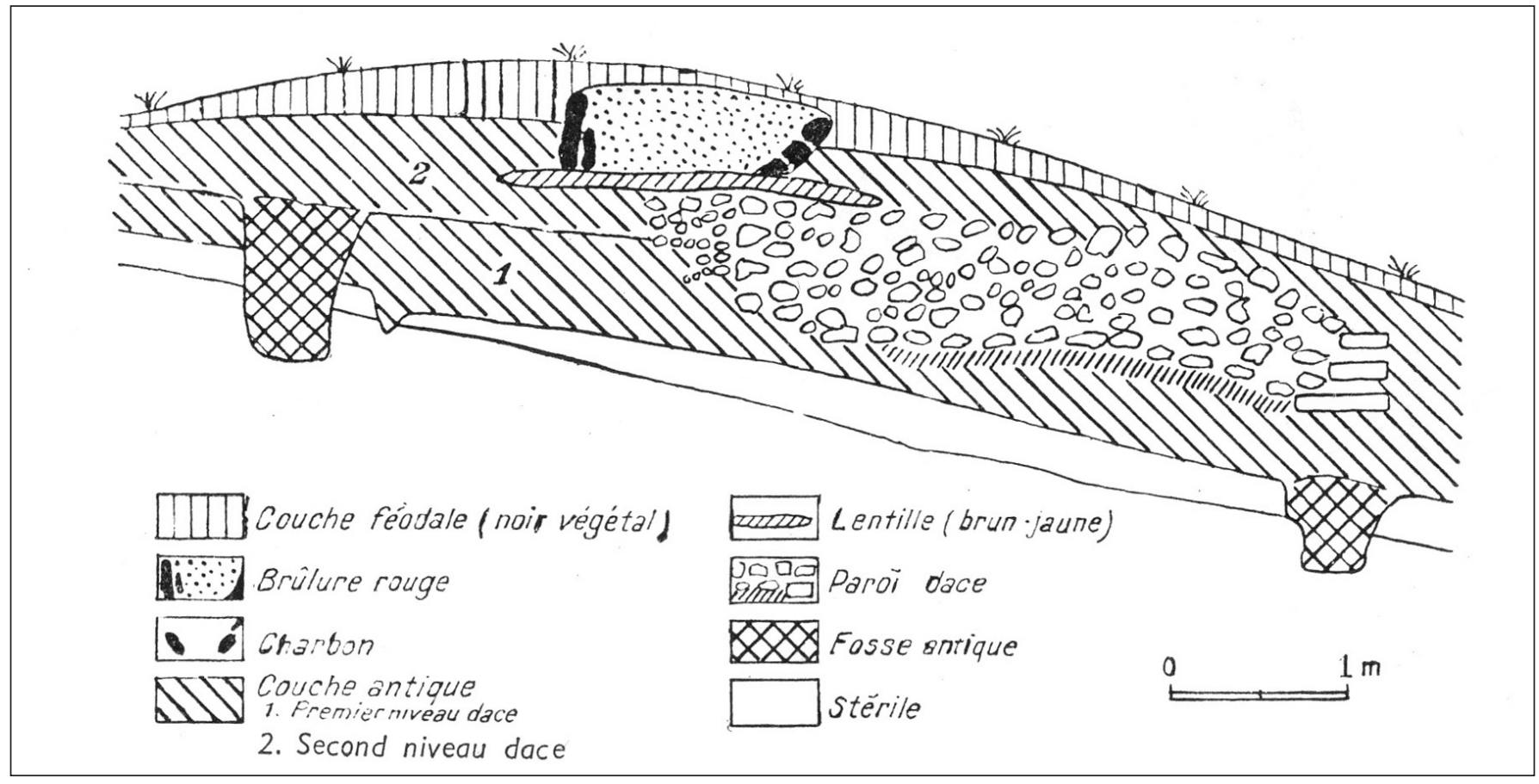

Fig. 6. Remains of a medieval palisade above the Dacian stone wall on the south side (SCORPAN 1965, 443, Fig. 3)

fortification was also indicated by a ruined wooden structure along an artificial bench on the western slope of the hill, which is lower than the level of the Iron Age terrace fortified with a stone wall (SCORPAN 1965, 441-442; Agrigoroarei 2008, 11-12). Medieval finds were also found sporadically or in clusters on the high ground and on the eastern edge of the fortification, where a thin layer of soil (max. $0.15 \mathrm{~m}$ thick), overlying a thick, ancient cultural layer, with evidence of surface structures, showed signs of contemporary activity. On a prominent terrace (Fig. 7) on the western side of the castle hill below the plateau, two buried ovens, an object interpreted as a hut (oval-shaped, $2.10 \mathrm{~m}$ long) in Trench no. 5, and two

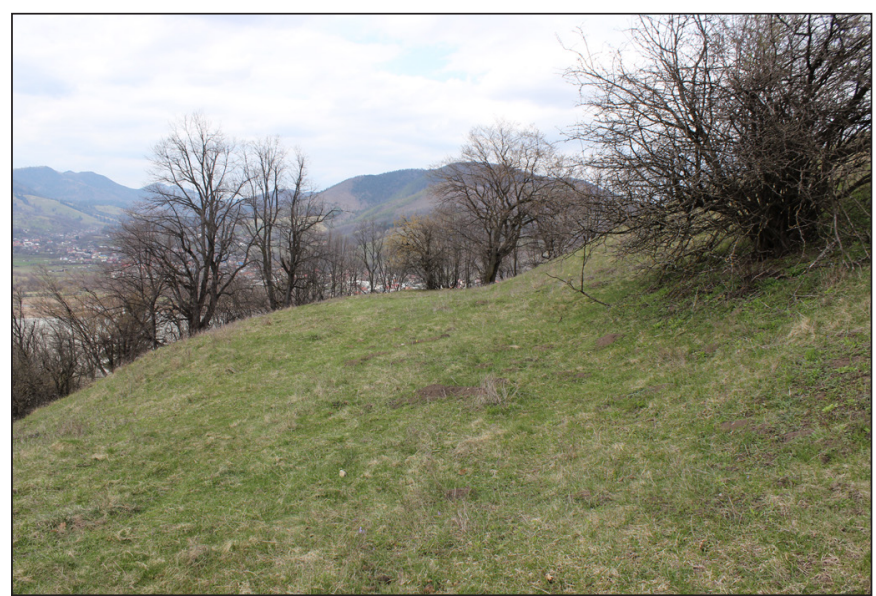

Fig. 7. The artificial terrace on the west side of the castle hill, viewed from the south (photo by the author) 
András Sófalvi $\bullet$ The Karácsonkö Castle: an Outpost on the Eastern Side of the Carpathians

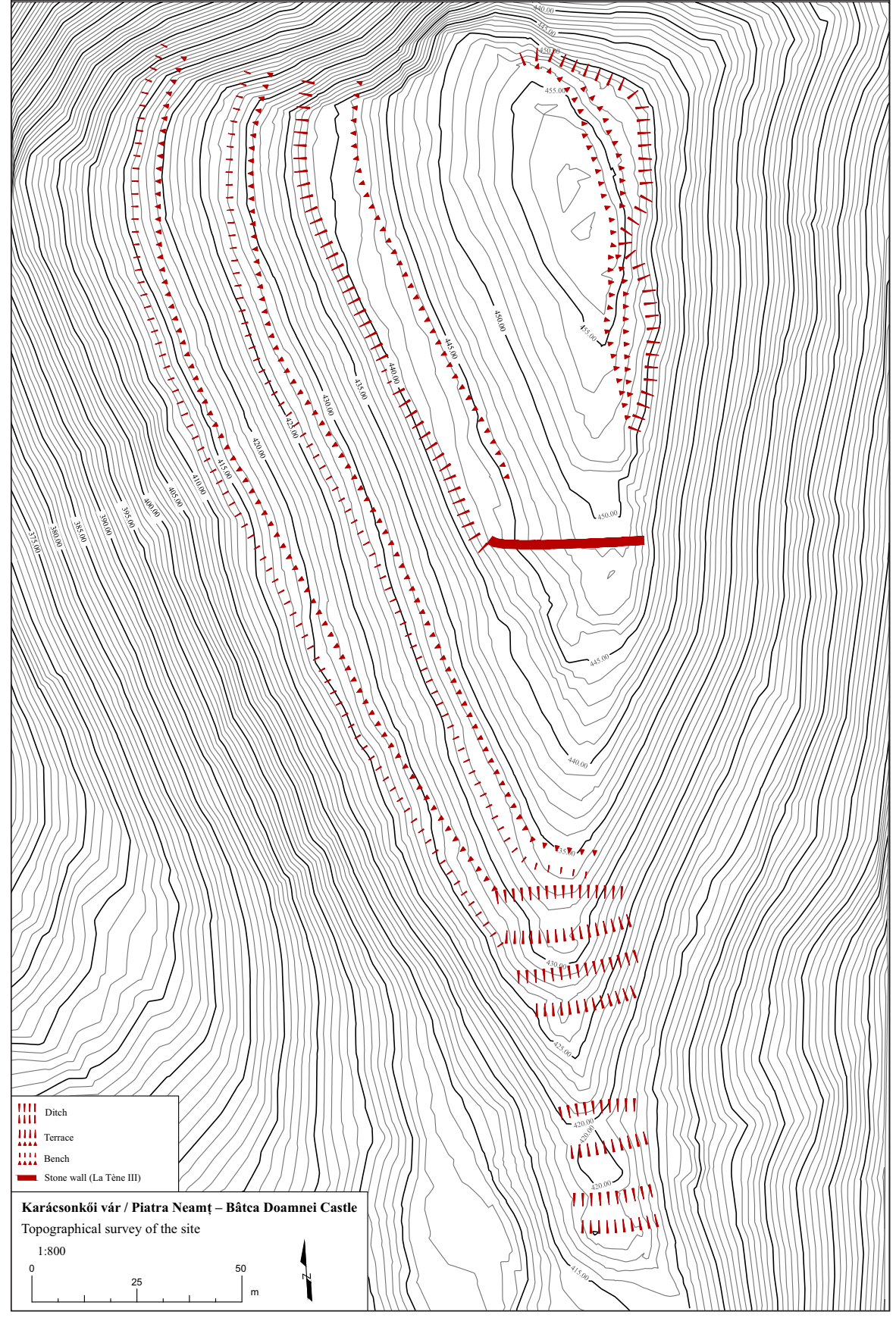

Fig. 8. Topographical survey of the castle hill (by the author and CloudScale Digital Ltd.) other ovens with medieval finds around them were discovered. In 1962, three graves oriented to the east were discovered in the castle, including a skeleton with injuries inflicted by a sword on the spine and another whose skull was missing. In 1965, ten further burials, probably also Christian, were found on the western terrace, including those of a woman and two children (Botezatu \& ŞTeFĂNESCU 1969, 13-18). Nearby, the remains of a timber structure were observed, and some researchers interpreted them later as a church (Gostar 1969, 12).

On the basis of the rather limited observations made during excavation and our present knowledge concerning the fortification's character and the internal structure of the castle, it was a fortress fortified with a wooden structure (palisade wall), widely used in the Árpád period, and with external defence lines (ditches, ramparts). Favourable geographical conditions made it unnecessary to construct massive ramparts on the periphery of the plateau. The medieval layout of the fortification has not been assessed in the past. The georeferencing and field application of a scale-free survey, recording Iron Age phenomena (the dimensions of the Prehistoric fortification was $170 \times 110 \mathrm{~m}$, see Gostar 1969, 7-16), has been used to locate the line of the former palisade ${ }^{3}$ Fig. 8).

\section{ARTEFACTS: VESSELS, UTENSILS, WEAPONS AND HARNESSES}

The medieval material heritage uncovered in the castle area represents essential information and offers the researcher a wide range of possibilities for interpretation. The number of pottery discarded as household refuse indicates a more intensive activity than at an average Árpád-period hill fortification. This group of artefacts consists mainly of pots with a widening upper third or a spherical body, with a short neck and a protruding, simply profiled rim. They are decorated with both equidistant and irregular incisions of straight

\footnotetext{
The survey was prepared with the professional assistance of CLOUDSCALE DIGITAL Ltd., and hereby I would like to thank Nándor Laczkó for his help.
} 


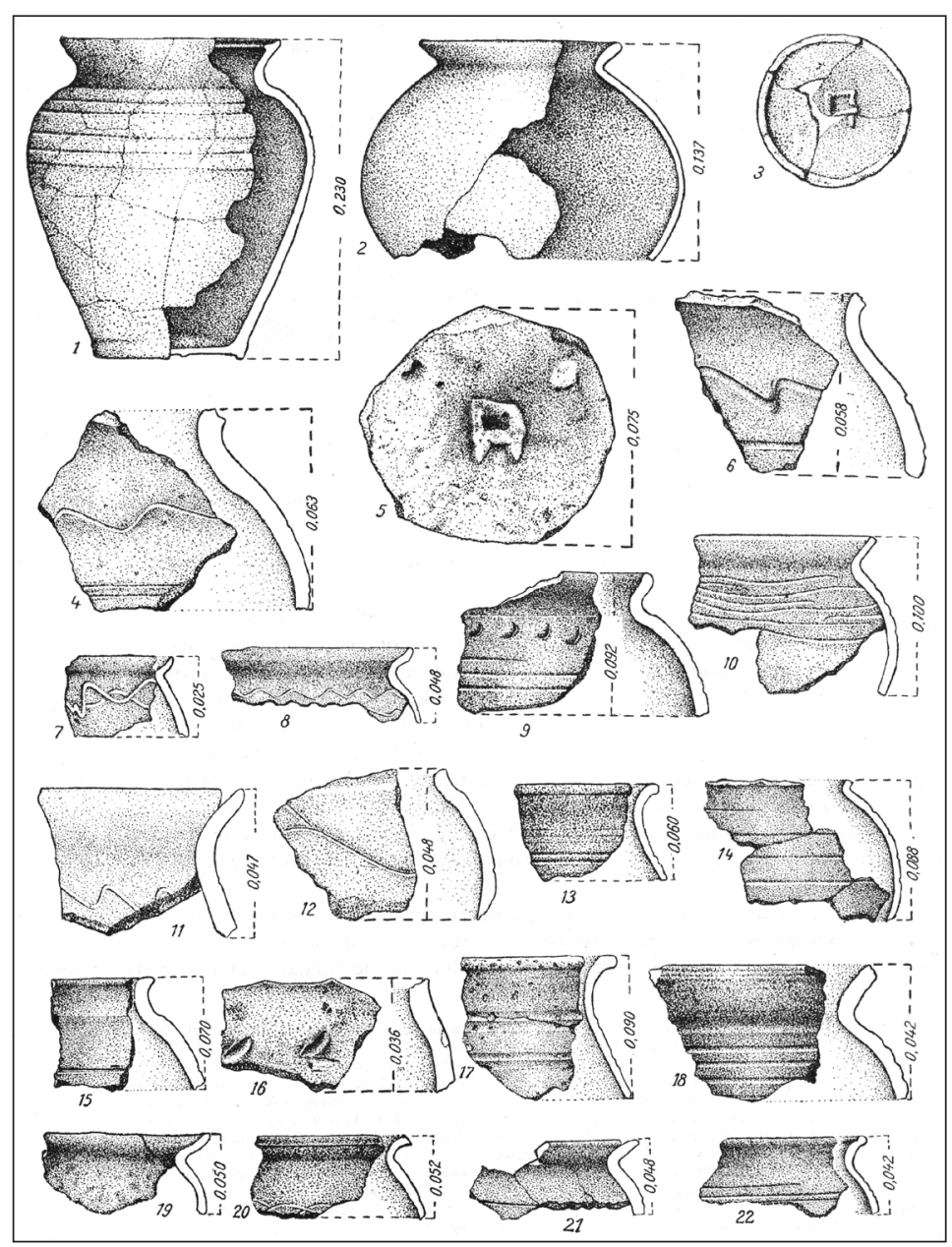

Fig. 9. Árpád-period artefacts from the castle (SCORPAN 1965, 444, Fig. 4)

and wavy lines, with frequent nail pinches on the shoulders and stamp on the bottom (SCORPAn 1965, 444, Fig. 4) (Fig. 9). On the other side of the mountains, in eastern Transylvania, similar vessel types are known from the area of the early fortifications of the Rika tower castles on the Perșani ridge and from the wood-and-earthwork fortification of Ugra on the banks of the Olt river (Sófalvi 2017, 202203, Fig. 505-511; Popa \& ŞTEFăNescu 1980, 496-503). Similar pottery fragments have also been found in castles in the Ciuc Basin (Racu - Pogányvár, Tuşnad - Vártetö) (see Botár 2019, 369, 601).

Metal tools and other metal objects attract attention not because of their quantity but because of their diversity. The weapons include a fully intact Western type double-edged sword and fragments of three other sword blades, cross-guards and pommels, a single-edged piece of blade (presumably belonging to a sabre), scabbards, several spearheads, tanged and socketed arrowheads, two Eastern type cast mace heads and an axe (MĂTASĂ \& ZAMoșteAnu 1960, 347; SCORPan 1965, 447, Fig. 5.1-5, 7-9; SPINEI 1982, Fig. 7.1-14, Fig. 23.2; AgrigoroAREI 2008, 15). It is worth highlighting here the sword with a boat-shaped pommel, which also has analogies in terms of dating. Its closest parallel is known from the Ciuc Basin (Cotormani), and two other similar examples were found in Covasna county (Micloșoara, Săsăuși) (BotÁR 2019, 557; Bordi 2008, 241-242, Pl. 2-3). In his monographic analysis of Transylvanian medieval swords, Zeno-Karl Pinter identified the exact counterpart of the sword of Karácsonkő in the sword of Coroi, found in the basin of the Târnava Mici, suggesting that the Moldavian find is most probably of Transylvanian origin (PINTER 2007, 88-89, P1. 39b). Among the accessories for riding and warfare on horseback, there are seven spiked spurs (three of them with encrusted decoration), a fragment of a spur with a star (?), and nine stirrups, with two main types (flat-soled western and curved-soled eastern), with several variations (MĂTASĂ \& ZAMOșTEANu 1960, 347; Scorpan 1965, 447-448, Fig. 5.11-15, Fig. 6; Spinei 1982, Fig. 7.15-17, Fig. 8; AgrigoroAREI 2008, 14-15). Some of the published iron buckles are harness parts (SCORPAN 1965, 447, Fig. 5.10, 16; Agrigoroarei 2008, 15). The preliminary publication also mentions horseshoes and bits (MĂTASĂ \& ZAMoșTEANu 1960, 347) (Figs 10-11). The diversity of the published weapon finds and the wide range of types raises the question whether they all belonged to the same type of military troops. Approaching the problem from the perspective of the stirrups, it is well known that round stirrups were not at all characteristic of the Magyar conquerors, much less of the Western cavalry, but three of the Karácsonkő finds belong to this group. The main characteristics of the type are the curved footplate and the ears forged into the shoulder, along with the frequent bulging at the junction of the footplate and the stems. This stirrup type is usually associated with the Pechenegs east of the Carpathians (SpinEI 1982, 139, Fig. 29.3-4, 6-7, Fig. 31.1-2, Fig. 34.1-2; PÁlóczi Horváth 2014, 31, Fig. 13-14), and their occurrence in the Carpathian Basin usually also implies their presence (Havassy 1996, 18; PÁlóczi Horváth 2014, 51, Fig. 30). This stirrup type, however, continued to be used by the Cumans, who settled in the territory of the Kingdom of Hungary in the 13th 
András Sófalvi $\bullet$ The Karácsonkö Castle: an Outpost on the Eastern Side of the Carpathians
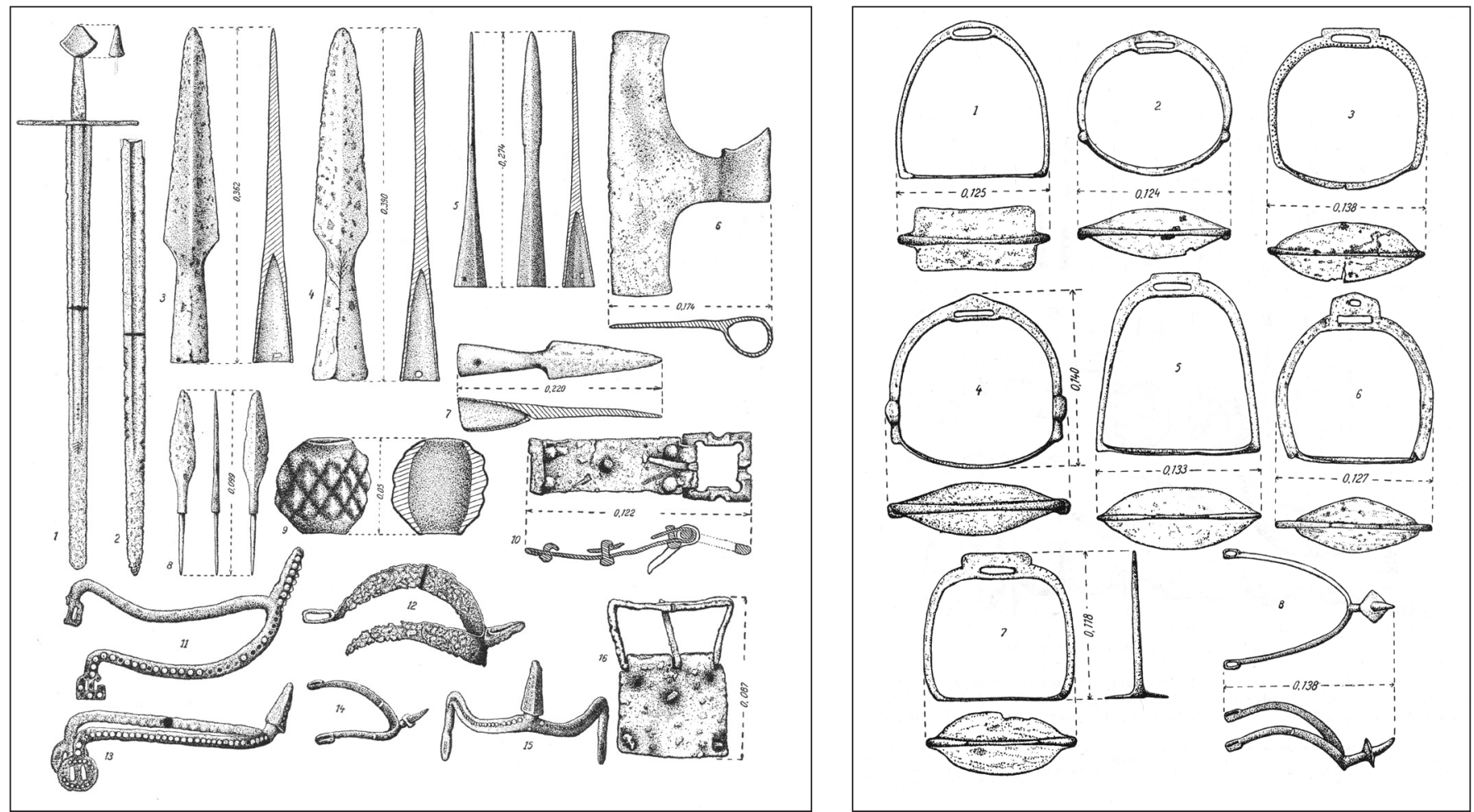

Figs 10-11. Weapons and horse harness elements (SCORPAN 1965, 447-448, Fig. 5-6)

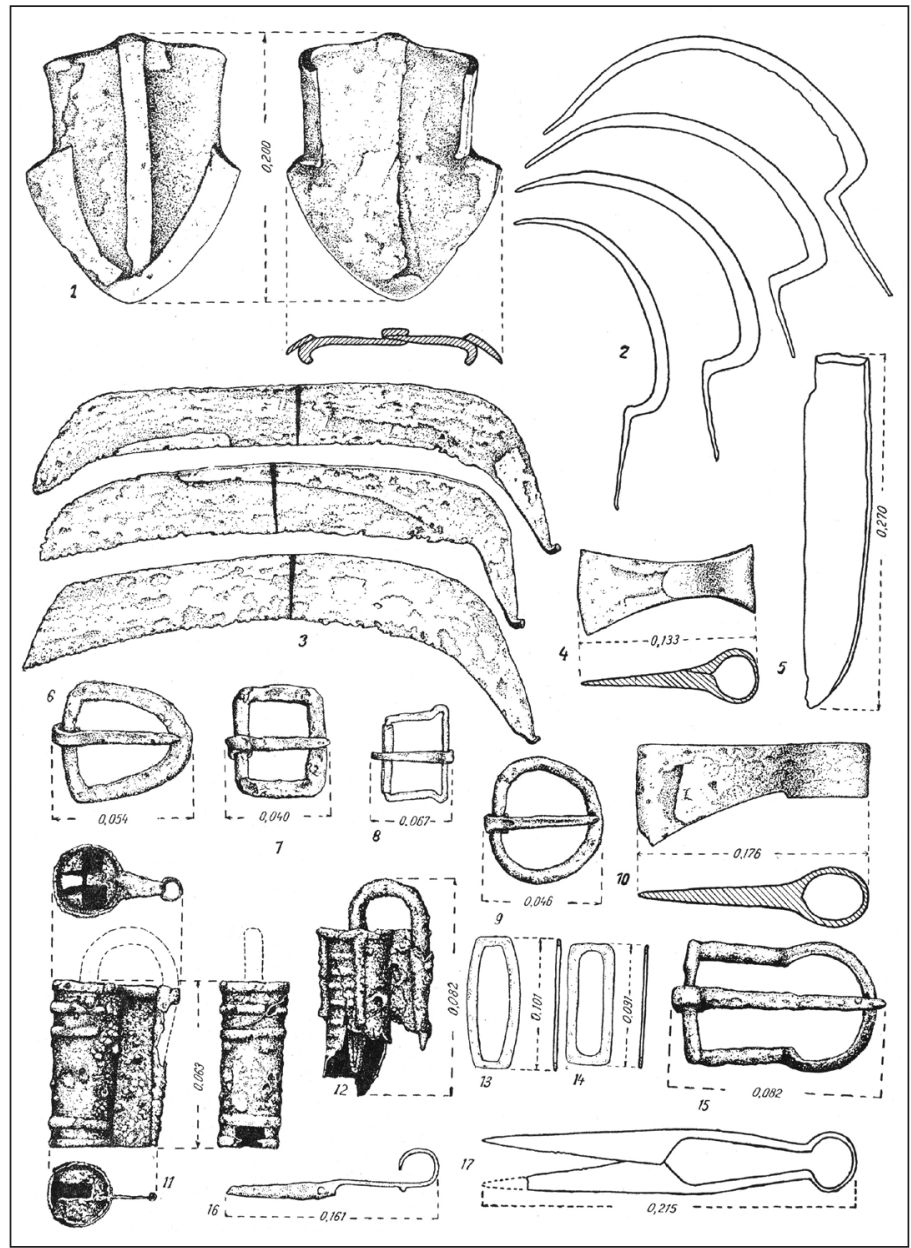

Fig. 12. Agricultural tools and objects of everyday use (SCORPAN 1965, 450, Fig. 7) century (Nagykamarás - Bánkút, Kunszentmárton - Jaksorérpart) (PÁLÓCZI HoRvátH 2014, 129, Fig. 85.1-2; KovÁcs 1986, 278). The "Pecheneg type" stirrup found along with 13th-14th-century objects in the Coşna hoard in Moldavia (SPINEI 1982, Fig. 34.1-2) also indicates that the object type is not exclusively related to the Pechenegs. On the basis of the weapons and cavalry equipment from Karácsonkő, one can state that the bulging stirrups are the accessories of lightly armed, mounted archers, possibly also carrying a mace, who did not use spurs, and the spears, swords, spiked spurs and straight-soled stirrups may be the material remains of the presence of a transitional type of cavalry.

Among the metal objects, the most striking is the presence of agricultural tools in the castle: an intact plough, a ploughshare, several scythes and sickles are among the finds (MĂTASĂ \& ZAMOȘTEANU 1960, 347; SCORPAN 1965, 450, Fig. 7.1-5, 10; Spinei 1982, Fig. 9; Agrigoroarei 2008, 14). Tools and utensils used in everyday farming further expand the range of metal objects: axes, anvils, hooks, flints, tweezers, scissors, padlocks and belt buckles (MĂTASĂ \& ZamoșteAnU 1960, 347; SCORPAN 1965, 450, Fig. 7.6-9, 11-17; Agrigoroarei 2008, 14) (Fig. 12). 
András Sófalvi • The Karácsonkö Castle: an Outpost on the Eastern Side of the Carpathians

\section{CHRONOLOGY}

Based on their analogies, the objects reviewed can be dated within a narrower or broader time range, but certain types of objects (e.g. spiked spurs and double-edged swords) basically place the focus of dating between the second half of the 12th and the middle of the 13th century. The most important items are a silver bracteate and a pectoral-cross reliquary (SCORPAN 1965, 451-452, Fig. 8-9; Agrigoroarei 2008. 13) (Fig. 13-14). At the same time, these two key finds have given rise to the most controversy in the interpretation of the function of the castle. In the first publication, the coin appeared as the mint of Béla IV (MĂTASĂ \& Zamoșteanu 1960, 347), but since Scorpan's study of medieval artefacts, Romanian scholars (Spinei, Agrigoroarei) have considered it to be a coin from the time of Béla III. Some Hungarian researchers are cautious about linking the mint type to a ruler (GYÖNGYÖsSY \& WINTER 2007, 63, Taf. 17.370-378). The coin design with a double cross above a T-shaped cross and two rosettes below shows a clear Byzantine influence, which was incorporated into the Hungarian royal symbols by Béla III (1172-1196). However, Béla IV (1235-1270) considered his grandfather to be his role model, both in terms of rule and symbolic manifestations. In the light of new research into numismatic history, most of the recent Árpád period coin catalogue date the bracteate to the beginning of the reign of Béla IV (before 1241), during his reign as

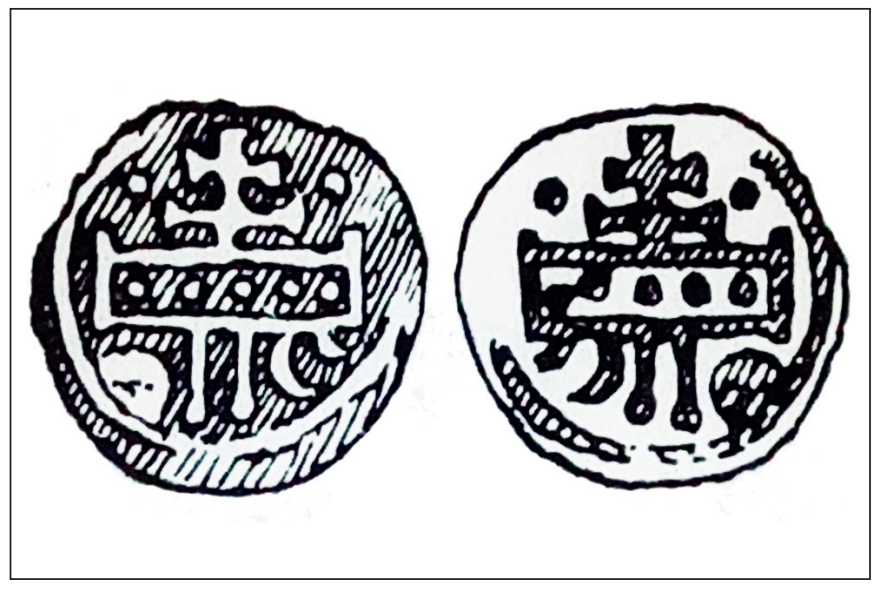

Fig. 13. Byzantine type cross (SCORPAN 1965, 452, Fig. 9)

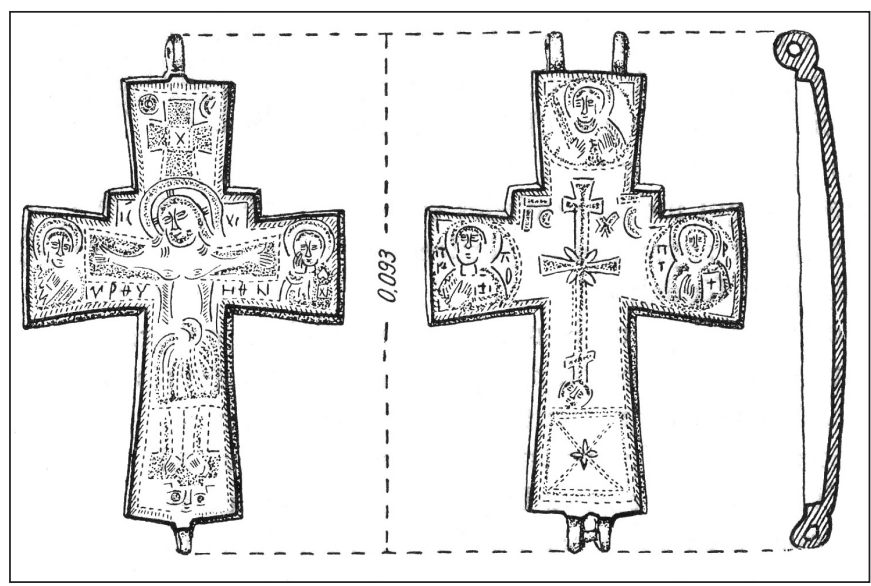

Fig. 14. Bracteate from the period of Béla IV (SCORPAN 1965, 451, Fig. 8)

Duke of Transylvania (То́тн \& KISs 2020, 17, 154, 22.7.1.1). Some unconfirmed theories about the castle are based on the bronze cast encolpion which probably has eastern origins. The hollow, Latin cross-shaped body consists of a front and a back plate fastened together by hinged straps, with slightly widening arms. The surface of the cross is decorated with niello figures. The front side represents the crucified Christ, girdled with glory, with a pedestal under his feet, and above him a small cross with the sun and the moon; next to Christ's outstretched arm are the figures of the Virgin Mary and St. John, with the abbreviations of their names in Greek letters engraved above and below the side arms of the cross. In the centre of the back of the corpus is a cross enclosed by the pair of letters IC XC, standing on the head of Adam; at the ends of the lateral arms of the cross there are medallions with busts inscribed Paul and Peter, and at the upper end of the vertical arm a medallion with the bust of St. Nicholas (see SPINEI 1982, 108).

Pectoral-cross reliquaries, usually called the Holy Land type, spread not only in the Middle East and the Byzantine Empire, but also in Latin rite communities (Italy, the Kingdom of Bohemia, and the Kingdom of Hungary) in the 10th-12th centuries (SzATHMÁRI 1995, 225; LANGÓ 2016, 64-65). Casting moulds from Bohemia and Hungary clearly show that such crosses were made not only in Eastern (Orthodox) but also in Western Christian areas. The preliminary publication of the archaeological material from Karácsonkő only mentioned the cross described above, but it was later revealed that two other so-called Kiev-type reliquary crosses were also discovered in the castle (SPINEI 1982, 88). Their presence indirectly indicates the existence of an important route between the Principality of Kiev and the Carpathian Basin (a Kiev-type pectoral-cross 
András Sófalvi • The Karácsonkö Castle: an Outpost on the Eastern Side of the Carpathians

reliquary on the inner side of the mountains is known from Cotormani) (see BотÁR 2019, 550, Fig. 528).

In the scholarly interpretation of the role of the fortification at Karácsonkö, certain groups of Western-type objects (double-edged swords, spiked spurs) are of crucial importance, as their presence at the site cannot be explained by trade relations, but rather by the presence of a military unit employing certain types of weapons and fighting styles (known in the literature as semi-light/semi-heavy or transitional cavalry), i.e. typical Hungarian warriors of the period, east of the Carpathians. This is a factor that researchers who follow a non-ideological methodological approach noticed from the very first moment, as it is almost unparalleled at other Moldavian sites. 13th-14th-century pommels are known as stray finds from Coșna in Suceava County (SPINEI 1982, Fig. 34-35). It is noteworthy that this site is located next to the route crossing the Bârgău Pass.

\section{CONNECTION WITH THE HINTERLAND - ROADS}

The shortest route from Transylvania to Karácsonkő in Moldova, through the gorge valley of the Bicaz Stream, is a modern achievement. The present-day line of the continuation of the road along the Bistrița Aurie-Bistricioara and the Tulgheș Gorge into Transylvania via Borsec, Toplița and the Mureș Gorge is also largely modern; the Mureș Gorge was not used in historical times. The so-called Salt Road, which runs from the Salt Region to the Gurghiu Plateau, is therefore of particular importance for our subject (its 13th century use is evidenced by a contemporary arrowhead - see Sófalvi 2017, 126, Fig. 53.8). It crossed the Giurgeu Mountains (a 14th-century broadsword was found nearby - cf. DEMJÉn 2016, 135, Fig. 1) from the Giurgeu Basin along the Pricske Peak towards the Tulgheș Gorge. The road had a south-eastern fork towards Bicaz-Chei (along the Balázs and Zsédán streams - see PusKás-Kolozsvári 2020, 190), from where it was easy to reach Karácsonkő. The existence of two other roads from the Transylvanian Basin to Karácsonkö, which date back to the Middle Ages, can be proven by historical geography: the so-called Bistrița Road from Bilbor and the road from Reghin, which led to Tulgheș via the valley of the Gurghiu Stream (PuskÁsKolozsváRi 2020, 190-193). The late Árpád-period settlement history of the Giurgeu Basin has begun to unfold in the course of archaeological research over the last decade or so (see DEMJÉn 2016).

\section{THE RELATIONSHIP BETWEEN CASTLES ON THE BORDER AND THE CONTEMPORARY CASTLE SYSTEM}

Research in recent decades has revealed the workings of the most important administrative institution of the Kingdom of Hungary in the Árpád period, the castle county (in Hungarian: várispánság), and the organisation of border defence has become increasingly clear (KRISTÓ 1988; ZsOLDOs 2000). In contrast to the western and central parts of Transylvania, the northern and eastern areas of the counties, the Someșu Mare-Șieu, the upper reaches of the rivers Mureș and the Târnava, and the Homorod valley were part of this border defence system according to indirect archaeological and linguistic data. It is striking that several earthworks with wooden structures, which were not county centres, were discovered by archaeological excavations in these regions, on the territory of the medieval counties, in the second half of the 20th century. These include the earthworks of Cuzdrioara, built at the confluence of the Someș rivers, Șirioara on the banks of the Șieu, and the Satu Nou/Cușma at the foothills of the Călimani Mountains. The castle from Morești, built opposite the mouth of the Niraj River on the banks of the Mureș, and the castle of Brâncovenești, mentioned in written sources (1228) but not known in detail, are also among these (SófALvi 2017, 74). Although there is no written data on the role of these 11th-12th-century fortifications in the border defence of Eastern Transylvania, it is reasonable to assume on the basis of the documentary evidence about similar constructions in other regions (the northern and western peripheries of the Kingdom of Hungary) that the fortifications were so-called castle counties without a county background, or castles serving as centres of border castle counties (cf. Zsoldos 2000, 115). In the region of the upper Târnava rivers, in the central part of the later Szeklerland, a forest county was presumably established on the private royal estate of Udvarhely in the end of the 12th century, similarly to the forest estates in the northern periphery of the kingdom. Castles were 
András Sófalvi $\bullet$ The Karácsonkö Castle: an Outpost on the Eastern Side of the Carpathians

also built in this area (the tower castles in the Rika Forest, with 12th century finds - see SófALVI, 2013), and they certainly played an important role in controlling the roads that led to the frontier.

The institutional relationship between the Karácsonkő castle and the network of counties behind the mountains will probably never be fully explored due to the complete lack of written sources on the region, but can, at most, be modelled: a border castle operating in a border county under the jurisdiction of a border castle county (the organisation of Sopron county along the western border is an analogy, see Zsoldos 2000, 115).

\section{THE ROLE OF KARÁCSONKŐ CASTLE IN THE FOREIGN POLICY OF THE AGE}

The fortification of Karácsonkő, built at the mouth of the valley of the Bistrița Aurie river, which flows towards Moldova, was more than a simple border castle, as its specific position indicates. Built on the outer periphery of the frontier, the castle was not merely a military factor, its builders intended it to play a more complex role. The outpost was created for the purpose of reconnaissance and monitoring population movements in the central and northern parts of Moldavia, but its geographical location also made it an excellent place of refuge.

In the period under study, one of the most important political factors was the Cumans on the outer side of the Carpathians. In the 12th century there was only indirect contact between the Kingdom of Hungary and the Cumans, and no open military conflict took place (Kovács 2014, 238). From the beginning of the 13th century, during the campaigns of András II (1205-1235) against Halych, the Cumans faced the conquering Hungarian armies on several occasions (KovÁcs 2014, 239-242). As a result of his conquests, the Hungarian ruler took the title of King of Galicia (Halych) and Lodomeria, but made his sons ascend to the throne of the principality (on the campaigns and the events at Halych, see MAKK 2000, 175-177; KRISTÓ 1998, 199-201, 221-222; Zsoldos 2009, 27-29). In most cases, the route of these conquering campaigns to Russia did not lead through Transylvania, however, this perspective must also be taken into consideration when the establishment of the fortification of Karácsonkő is discussed.

From the mid-1220s, the question of the Cumans became a matter of ecclesiastical politics, and the Kingdom of Hungary, with the support of the papacy, began to convert the Cumans. One of the main supporters of the conversion in the Hungarian royal court was Prince Béla, who came to rule Transylvania in 1226, and most of his Transylvanian charters he issued as the younger king related to his plans for Cumania (KRISTó 2003, 209-211; Zsoldos 2009, 30, 44-45). In less than a decade and a half, the Christian conversion in the Cuman territories beyond the Carpathians achieved great success thanks to the activities of the Dominican friars, and a new diocese was established outside the borders of the country (the Bishopric of Milkov in 1227). In addition to Archbishop Robert of Esztergom and three bishops, Prince Béla also took part in the baptism of one of the Cuman princes, Bortz and his retinue, which gave the action a considerable political importance (KovÁcs 2014, 246-249). The political consequences of the conversion is shown by the fact that in 1233, Andrew II also assumed the title of rex Cumaniae (KovÁcs 2014, 253-255). The territory of the Cuman bishopric became a Hungarian sphere of interest, and its integration into the administrative system of the Hungarian kingdom began. The foundations of this are still little understood but this may have been the moment when Karácsonkő became the seat of a border castle county and the development of the characteristic castle organisation began. Pope Gregory IX, in his diploma of November 1234, mentioned the Hungarian, German and other believers who had migrated beyond the mountains here (JAKÓ 1997, 173).

\section{THE END: THE MONGOL INVASION}

It was the Mongol/Tatar invasion that put an end to the existence of the castle of Karácsonkö. This is evidenced not only by the burnt layers/fire traces observed in the castle. The date range of the published archaeological finds is one of the most important pieces of evidence in this respect, as they do not go beyond the mid-13th century. The variety of material remains and the above-average richness of the metal artefacts left behind are also decisive in this respect. Considering all of the above factors, one can conclude that the remains of the castle at Karácsonkő do not merely preserve the imprint of everyday life there, but 
András Sófalvi • The Karácsonkö Castle: an Outpost on the Eastern Side of the Carpathians

they represent the archaeological legacy of the small military contingent stationed in the castle, and also the remains of the material culture of a multi-status, multi-ethnic population that fled here with their valuables from a wider area, from the foothills of the mountains overlooking to Moldova, in order to escape the Mongols' devastating military attack. Some of those who fell in battles were buried here, and the anomalies observed on some of the skeletons are evidence of a violent attack. By this period, the practice of burial around the church had become a strict ecclesiastical rule in the Kingdom of Hungary, and exceptions were only imaginable under unusual circumstances (battles, epidemics, etc.). Some burials have been discovered within medieval castles, for example in Transylvania in the Porumbenii Mari Castle or on the castle hill of Târnava in Transylvania (SóFALvi 2017, 136, note 987). These, however, are also the results of unusual events (violence, armed confrontation).

The survivors who managed to escape from Karácsonkő by mountain roads or little-used paths towards Transylvania, hardly had the opportunity to return and salvage the values they had left in the castle. The Mongol invasion brought about lost battles, the destruction of settlements, the burning of churches, monasteries and houses, and serious population loss, and it resulted in a fundamental transformation of the Árpád-period institutional system and started the process that led to the disintegration of the royal county and the castle organisation system in the following decades. The expansion beyond the mountains and the role of the castle of Karácsonkö ceased after the Mongol invasion, and no Hungarian garrison was stationed there subsequently.

\section{BIBLIOGRAPHY}

Agrigoroarei, V. (2008). Horodiştea de la Bâtca Doamnei. In Sălăgeanu, V. (ed.), 12 monumente din istoria românilor (pp. 11-18). Bucureşti - Cluj-Napoca.

Bordi, Zs. L. (2008). Középkori kardok a Székely Nemzeti Múzeum gyüjteményeiben. Acta Siculica - A Székely Nemzeti Múzeum Évkönyve. Sepsiszentgyörgy: Sámán Kiadó.

Botár, I. (2019). Havasok keblében rejtözö szép Csík. A Csíki-medence középkori településtörténete. Budapest: Martin Opitz Kiadó.

Botezatu, D. \& Ştefănescu, Gh. (1970). Contribuţii la studiul antropologic al populaţiei feudale timpurii din Moldova din sec. XIII e. n. Studii şi Cercetări de Antropologie 7 (1), 13-18.

Demjén, A. (ed.) (2016). Gyergyószentmiklós a régészeti kutatások tükrében. Kolozsvár - Gyergyószentmiklós: Erdélyi Múzeum-Egyesület - Tarisznyás Márton Múzeum.

Gostar, N. (1969). Cetăţi dacice din Moldova. București: Editura Meridiane.

Gyöngyössy, M. \& Winter, H. (2007). Münzen und Medaillen des Ungarischen Mittelalters 1000-1526. In Alram, M. \& Winter, H. (hrsg.) Milano - Wien: Skira - Kunsthistorisches Museum.

Havassy, P. (ed.) (1996). Zúduló sasok. Új honfoglalók-besenyők, kunok, jászok-a középkori Alföldön és a Mezöföldön. Gyulai katalógusok 2. Gyula: Erkel Ferenc Múzeum.

Jakó, Zs. (1997). Erdélyi Okmánytár. I. 1023-1300. Budapest: Akadémiai Kiadó.

Kovács, L. (1986). Viselet, fegyverek. In Kristó, Gy. Az Árpád-kor háborúi. Budapest: Akadémiai Kiadó. 
András Sófalvi $\bullet$ The Karácsonkö Castle: an Outpost on the Eastern Side of the Carpathians

Kovács, Sz. (2014). A kunok története a mongol hódításig. Magyar Östörténeti Könyvtár 29. Budapest: Balassi Kiadó.

Kristó, Gy. (1988). A vármegyék kialakulása Magyarországon. Budapest: Magvető Kiadó.

Kristó, Gy. (1998). Magyarország története 895-1301. Budapest: Osiris Kiadó.

Kristó, Gy. (2003). A korai Erdély (895-1324). Szeged: Szegedi Középkorász Mühely.

Langó, P. (2016). A négyszállási I. temető bronz keresztjei. In E. Bánkiné Molnár (ed.), Vízöntő. Ünnepi kötet a Jászságról Bathó Edit tiszteletére (pp. 67-75). Szolnok: Damjanich János Múzeum.

Makk, F. (2000). A tizenkettedik század története. Budapest: Pannonica Kiadó.

Mályusz, E. (1951). Zsigmondkori oklevéltár. I. 1387-1399. Budapest: Akadémiai Kiadó.

Mătasă, C. \& Zamoșteanu, I. (1960). Săpăturile de la Piatra Neamț. Materiale şi Cercetări Arheologice 7, 339-349.

Mikecs, L. (1943). A Kárpátokon túli magyarság. In J. Deér. \& L. Gáldi (eds), Magyarok és románok (pp. 441-507). A Magyar Történettudományi Intézet Évkönyve. Budapest: Athenaeum.

Pálóczi Horváth, A. (2014). Keleti népek a középkori Magyarországon. Besenyők, úzok, kunok és jászok müvelödéstörténeti emlékei. Budapest - Piliscsaba: Archeolingua.

Pinter, Z-K. (2007). Spada şi sabia medievală în Transilvania şi Banat (secolele IX-XIV). Bibliotheca Brukenthal VII. Sibiu: Muzeul Național Brukenthal.

Popa, R. \& Ştefănescu, R. (1980). Şantierul arheologic Ungra. Jud. Braşov. Materiale şi Cercetări Arheologice 14, 496-503.

Puskás-Kolozsvári, F. (2020). A Tászok-tető írott köveinek lehetséges párhuzamairól, különös tekintettel a moldvai területeken levőkre. In B. Fehér \& G. Ferenczi (eds), Ösi írásaink. Tanulmánykötet a Magyarságkutató Intézet által 2019. december 12-13-án rendezett konferencián elhangzott elöadásokból (pp. 183-199). Budapest: Magyarságkutató Intézet.

Scorpan, C. (1965). L’ensemble archéologique féodal de Bîtca Doamnei. Dacia N. S. 9, 441-454.

Sófalvi, A. (2013). Egy disszertáció margójára: a Rika-erdei várak és az udvarhelyi királyi magánuradalom kérdése. In E. Egyed, L. Pakó \& A. Weisz (eds), Certamen I. Elöadások a Magyar Tudomány Napján az Erdélyi Múzeum-Egyesület I. szakosztályában (pp. 165-174, 525-530). Kolozsvár: Erdélyi Múzeum-Egyesület.

Sófalvi, A. (2017). Hadakozás és önvédelem a középkori és fejedelemség kori Udvarhelyszéken. Kolozsvár: Erdélyi Múzeum-Egyesület.

Spinei, V. (1982). Moldova în secolele XI-XIV. Bucureşti: Editura Științifică și Enciclopedică.

Szathmári, I. (1995). Bizánci típusú ereklyetartó mellkeresztek Békés és Csongrád megyében. Móra Ferenc Múzeum Évkönyve - Studia Archaeologica 1, 219-264. 
András Sófalvi • The Karácsonkö Castle: an Outpost on the Eastern Side of the Carpathians

Tóth, Cs. \& Kiss, J. G. (2020). Az Árpád-kori magyar pénzek katalógusa III. - II. Andrástól Ottóig. Catalogue of Árpádian Coinage III. From King Andrew II to King Otto. Opitz Numismatica 3. Budapest: Martin Opitz Kiadó.

Zsoldos, A. (2000). Confinium és marchia. (Az Árpád-kori határvédelem néhány intézményéről). Századok 134 (1), 99-116.

Zsoldos, A. (2009). Nagy uralkodók és kiskirályok a 13. században. Magyarország története 4. Budapest: Kossuth Kiadó. 